\title{
TITIK TEMU EPISTEMOLOGI BARAT DAN ISLAM
}

\section{Akhmad Muzakki}

Fakultas Humaniora dan Budaya Universitas Islam Negeri Maulana Malik Ibrahim Malang, Jalan Gajayana No.50 Malang, HP. 081334701468, e-mail: akh.zakky@gmail.com

\section{Abstract}

Beside ontology and axiology, the object of philosophy of science is epistemology that discusses the truth of, the method of finding, and the reality of science. In epistemology, there are many schools discussing the process of finding the truth of science, such as, rationalism, empiricism, criticism, phenomenology, positivism, pragmatism etc. In the trilogy of Islamic teachings, that is, iman (faith), Islam, and ihsan (perfection), generally sciences in Islam can be classified into three branches of study: (1) Ilmu Tauhid (theology), this science makes use of intellectual ability or logic (burhani method) which is epistemologically identical with rationalism; (2) Ilmu Figh (Islamic laws), this frequently uses bayani method, that is, inductive and deductive framework, in epistemology this method is called empiricism; (3) Ilmu Tasawuuf (mysticism), this science uses the power and purity of heart, it is called irfani method that is similar to phenomenology in Western philosophy of science. Therefore, epistemologically, basically the development of sciences in Islam cannot be separated from Western epistemological schools, that is, rationalism, empiricism, and phenomenology as well.

Key words: Epistemology, rationalism (burhani), empiricism (bayani), dan phenomenology (irfani)

Ulul Albab, Vol. 10, No. 1, 2009 


\section{Pendahuluan}

Memasuki abad ke-20 filsafat banyak menyoroti tentang cara kerja maupun dasar teoritis semua ilmu secara tajam. Ilmu merupakan kumpulan pengetahuan yang mempunyai ciri-ciri tertentu, yang membedakan ilmu dengan pengetahuan lainnya. Secara filosofis ilmu memang berbeda dari pengetahuan, namun dalam perbedaan itu tidak terdapat hal-hal yang prinsip di mana keduanya mempunyai ciri-ciri keilmuan yang sama. Filsafat mempelajari masalah perbedaan tersebut dengan sedalam-dalamnya dan dari hasil pengkajiannya merupakan dasar bagi eksistensi ilmu.

Pada awal kelahirannya apa yang disebut filsafat itu sesungguhnya mencakup seluruh ilmu pengetahuan. Kemudian filsafat itu berkembang sedemikian rupa menjadi semakin rasional dan sistematis. Seiring dengan perkembangan itu, wilayah pengetahuan manusia semakin luas dan bertambah, tetapi juga semakin mengerucut. Lalu lahirlah berbagai disiplin ilmu pengetahuan yang satu persatu mulai memisahkan diri dari induknya, yaitu filsafat, misalnya filsafat agama, filsafat hukum, filsafat sejarah, filsafat ilmu, filsafat bahasa, dan sebagainya.

Filsafat ilmu merupakan telaah yang secara filosofis ingin menjawab beberapa pertanyaan mengenai hakikat ilmu, seperti: (1) Obyek apa yang ditelaah ilmu? (2) Bagaimana cara kita memperoleh pengetahuan yang berupa ilmu? (3) Dan apa nilai pengetahuan yang berupa ilmu tersebut bagi kita? Pertanyaan yang berkaitan dengan nomor satu menjadi landasan ontologis, yang berkaitan dengan nomor dua menjadi kajian epistemologis, dan yang berkaitan dengan nomor tiga menjadi garapan aksiologis (Suriasumantri, 1993: 33).

Diakui bahwa cara berpikir falsafati telah mendobrak pintu serta tembok-tembok tradisi dan kebiasaan, bahkan telah menguak mitos serta meninggalkan cara berpikir mistis. Pada yang sama telah pula berhasil mengembangkan cara berpikir rasional dan mendalam, integral dan koheren, metodis dan sistematis, logis, kritiș, dan analitis. Karena itu, ilmu pengetahuan semakin bertumbuh subur, terus berkembang dan menjadi dewasa. 
Begitu besarnya sumbangan filsafat terhadap pengembangan ilmu pengetahuan membuat para ahli pendidikan berkomentar, sekaligus menyoroti bahwa dunia pendidikan yang berkembang saat ini kurang bertolak dari atau belum dibangun oleh landasan filosofis yang kokoh, sehingga berimplikasi pada kekaburan dan ketidakjelasan arah dan jalannya pelaksanaan pendidikan itu sendiri. Seperti yang diungkap Ma'arif, setelah menyajikan dialog antara Iqgal dan Rumi dalam konteks pendidikan Islam, ia berkesimpulan bahwa fondasi filosofis yang mendasari sistem pendidikan Islam selama ini masih rapuh, terutama tampak pada adanya bentuk dualisme dikotomis (Ma'arif, 1993: 150). Karena itu, hubungan antara filsafat (filsafat Ilmu) dan pendidikan merupakan suatu keharusan untuk menjawab persoalan-persoalan pokok dan mendasar, terlebih pada kajian epistemologi sebagai paradigma dalam pengembangan keilmuan.

\section{Epistemologi dalam Perspektif Pemikir Barat dan Islam}

Secara etimologikal, epistemologi merupakan gabungan yang diangkat dari dua kata dalam bahasa Yunani, yaitu episteme dan logos. Episteme artinya pengetahuan, dan logos lazim dipakai untuk menentukan pengetahuan sistematik. Sehingga dengan mudah dipahami bahwa epistemologi adalah pengetahuan sistematik mengenai pengetahuan. Episteme bukanlah satusatunya kata dalam bahasa Yunani yang mempunyai arti pengetahuan dan pengertian. Ada beberapa kata yang memiliki makna sama dengan epistemologi, namun obyek dan ruang lingkupnya berbeda, misalnya gnosis, logos, dan sophia (bahasa Yunani).

Gnosis berasal dari kata gignosko, yang mendekati arti menyelami, memahami. Karena itu kata episteme lebih mengandung arti pengetahuan sebagai suatu upaya intelektual untuk menempatkan sesuatu di dalam kedudukan setepatnya. Sedang kata gnosis lebih mendekati pengetahuan dalam arti pengetahuan batin. Juga dengan logos, secara etimologis berarti pikiran, berdekatan dengan kata nous yang artinya budi. Kadang-kadang epistemologi juga disebut logika, yaitu ilmu tentang pikiran. Tetapi orang membuat perbedaan antara logika minor dan logika mayor. Logika minor 
mempelajari struktur berpikir dan dalil-dalilnya, seperti silogisme. Dan logika mayor mempelajari pengetahuan, kebenaran, kepastian yang sama dengan lingkup epistemologi. Berpikir logis belum tentu berpikir kritis. Penalaran yang sudah teratur belum tentu mengandung kebenaran dan kepastian. Dan yang terakhir adalah sophia, artinya pengetahuan, tetapi lebih mendekati kepada kebijaksanaan dan kearifan. Dari kata ini kemudian muncul philosophia, yang berarti cinta akan kebijaksanaan (Pranaka, 1987: 3-5).

Mengutip Dagobert, epistemologi merupakan cabang filsafat yang menyelidiki tentang keaslian pengertian, struktur, metode dan validitas ilmu pengetahuan (D. Runes, 1971: 94). Secara terminologis, sebagaimana pendapat Bakker yang dikutip Miska Muhammad Amien, bahwa epistemologi memiliki kesamaan dengan metodologi, yang dipahami sebagai filsafat ilmu pengetahuan. Filsafat ilmu pengetahuan yang dimaksud ini menguraikan metode ilmiah sesuai dengan hakikat pengertian manusia. Miska juga mengutip pendapat The Liang Gie, yang menyatakan, epistemologi sebagai cabang filsafat yang bersangkutan dengan sifat dasar dan ruang lingkup pengetahuan, praanggapan-praanggapan dan dasar-dasarnya serta realibilitas umum dari tuntutan akan pengetahuan (Amin, 1983: 2). Sementara menurut Muhammad Taqi Misbah Yazdi, epistemologi adalah bidang filsafat yang membahas pengetahuan manusia dalam berbagai jenis dan ukuran kebenarannya (Yazdi, 2003: 8).

Jadi epistemologi bersangkutan dengan masalah-masalah: (1) filsafat, yaitu sebagai cabang filsafat yang berusaha mencari hakikat dan kebenaran pengetahuan, (2) metode, sebagai metode bertujuan mengantar manusia untuk memperoleh pengetahuan, dan (3) sistem, sebagai suatu sistem bertujuan memperoleh realitas kebenaran pengetahuan itu sendiri.

Epistemologi, atau teori pengetahuan membahas secara mendalam segenap proses yang terlihat dalam usaha kita untuk memperoleh pengetahuan. Ilmu merupakan pengetahuan yang didapat melalui proses tertentu yang dinamakan metode keilmuan. Metode inilah yang membedakan ilmu dengan buah pemikiran lainnya. Atau dengan perkataan lain, ilmu adalah pengetahuan yang diperoleh dengan menerapkan metode keilmuan.

Ulul Albab, Vol. 10, No. 1, 2009 
Karena ilmu merupakan bagian dari pengetahuan, yakni pengetahuan yang memiliki sifat-sifat tertentu, maka ilmu dapat juga disebut pengetahuan keilmuan (Suriasumantri, 1999: 3-8).

Dalam filsafat Islam, kalau kita mengacu kepada al Quran disebutkan bahwa ada dua bidang (objek) pengetahuan, yaitu yang tampak dan yang gaib, yang tampak dapat diketahui manusia dan ia merupakan obyek kajian sains. Sedangkan yang gaib, meskipun dapat diketahui dengan cara yang berbeda in merupakan wilayah wahyu. Hal ini dapat dimengerti mengingat tidak adanya bukti fisik yang bisa kita terima (Leaman, 2001: 66).

Ada dua pertanyaan yang tidak bisa ditinggalkan dalam setiap sistem epistemologi mana pun, yaitu: (1) apa yang dapat kita ketahui? (2) Bagaimana mengetahuinya' Yang pertama mengacu pada teori dan isi ilmu, sedangkan yang kedua pada metodologi. Terhadap pertanyaan pertama, epistemologi Barat menjawab bahwa yang dapat kita ketahui adalah segala sesuatu sejauh ia dapat diobservasi secara inderawi. Hal-hal lain yang bersifat non-inderawi, nonfisik, dan metafisika, tidak termasuk ke dalam obyek yang dapat kita ketahui secara ilmiah.

Berbeda dengan pandangan epistemologi Barat, para ilmuwan muslim berpendapat bahwa kita bisa mengetahui bukan hanya obyekobyek fisik, melainkan juga obyek-obyek nonfisik. Karena itu, dalam epistemologi Islam kita bisa mengenal entitas-entitas nonfisik, seperti konsep-konsep mental dan metafisika, di samping entitas-entitas fisik lainnya. Demikian juga tidak mustahil bagi kita untuk mengetahui makhluk-makhluk halus, seperti jin, malaikat, dan ruh, di samping bendabenda fisik yang kita jumpai di dunia ini.

Dari kerangka berpikir seperti ini, epistemologi Islam telah berhasil menyusun klasifikasi ilmu yang komprehensif dan disusun secara hierarkis, yaitu metafisika menempati posisi tertinggi, disusul matematika, dan terakhir ilmu-ilmu fisik. Dari trikotomi seperti itu lahir berbagai disiplin ilmu rasional dalam dunia Islam, seperti ontologi, teologi, kosmologi, angelologi, dan eskatologi yang termasuk ke dalam kategori ilmu-ilmu metafisika, geometri, aljabar, aritmetika, musik, dan trigonometri yang termasuk ke dalam kategori 
ilmu-ilmu matematika, dan fisika, kimia, geologi, geografi, astronomi, optika dan sebagainya yang masuk dalam kategori ilmu-ilmu fisik (Bakar, 1997: 120-131).

Terkait dengan pertanyaan kedua, bagaimana kita mengetahui obyek-obyek ilmu yang beraneka tersebut? Pertanyaan ini jelas menyangkut metodologi yang digunakan para filosof dan sufi. Metode ilmiah yang dikembangkan para pemikir muslim berbeda secara signifikan dengan metode ilmiah yang dikembangkan oleh pemikir Barat. Sebab itu, Ziauddin Sardar berkata, para ilmuwan Barat menggunakan hanya dengan satu macam metode ilmiah, yaitu metode observasi, sementara para pemikir muslim menggunakan tiga macam metode sesuai dengan tingkat atau hierarki obyek-obyeknya, yaitu: (1) metode observasi (bayani), sebagaimana yang digunakan di Barat, (2) metode logis atau demonstratif (burhani), dan (3) metode intuitif (irfani), yang masing-masing bersumber pada indera; akal, dan hati (Kartanegara, 2002: 62).

Jika dikatakan bahwa seseorang mengetahui sesuatu, berarti ia memiliki pengetahuan tentang sesuatu itu. Dengan demikian, pengetahuan adalah suatu kata yang digunakan untuk menunjuk kapada apa yang diketahui oleh seseorang tentang sesuatu. Pengetahuan senantiasa memiliki subyek, yakni yang mengetahui, karena tanpa ada yang mengetahui tidak mungkin ada pengetahuan. Jika ada subyek, pasti ada obyek, yakni sesuatu yang ihwalnya kita ketahui atau hendak kita ketahui. Tanpa obyek, tidak mungkin ada pengetahuan. Pengetahuan bertautan erat dengan kebenaran karena demi mencapai kebenaranlah pengetahuan itu eksis. Kebenaran ialah kesesuaian pengetahuan dengan obyeknya. Ketidaksesuaian pengetahuan dengan obyeknya disebut kekeliruan (Rapar, 1996: 38).

Pertanyaan kebih lanjut yang harus dihadapi epistemologi adalah tentang kebenaran. Telaah epistemologi membawa orang kepada suatu kesimpulan bahwa perlu dibedakan adanya tiga jenis kebenaran. Pertama kebenaran epistemologiksal, yaitu pengertian kebenaran dalam hubungannya dengan pengetahuan manusia. Kedua kebenaran ontologikal, yaitu kebenaran sebagai sifat dasar yang melekat kepada segala sesuatu yang ada ataupun 
diadakan, dan ketiga kebenaran semantikal, yaitu kebenaran yang terdapat serta melekat di dalam tutur kata dan bahasa (Pranaka, 1987: 43).

Kriteria (teori) kebenaran dapat dibedakan kepada; (1) Teori koherensi yaitu suatu pernyataan dianggap benar bila pernyataan itu bersifat koheren atau konsisten dengan pernyataan-pernyataan sebelumnya yang dianggap benar. Plato (427-347 SM) dan Aristoteles (384-322 SM) mengembangkan teori ini berdasarkan pola pemikiran yang dipergunakan Euclid dalam menyusun ilmu ukurnya. (2) Teori korespondensi yaitu suatu pernyataan adalah benar jika materi pengetahuan yang dikandung pernyataan itu berkorespondensi (berhubungan) dengan obyek yang dituju oleh pernyataan tersebut. Eksponen teori ini adalah Bertrand Russel (1872-1970). (3) Teori pragmatis yaitu suatu pernyataan diukur dengan kriteria apakah pernyataan tersebut bersifat fungsional dalam kehidupan praktis. Teori ini dicetuskan Charles S. Peirce (1839-1914) yang kemudian dikembangkan oleh beberapa ahli filsafat yang kebanyakan berkebangsaan Amerika. Di antaranya, John Dewey (1859-1952), George Herbert Mead (1863-1931), dan C. I. Lewis (Suriasumantri, 1999: 55).

Mengutip Mulyadhi, ada dua metode dalam upaya mendekati kebenaran, yaitu: (1) metode empiris, dan (2) metode logis. Jalan empiris tentu saja mengacu pada metode inderawi karena mengandalkan pencerapan indera lahir, terutama indera penglihatan sehingga sering disebut observasi, yang arti dasarnya adalah melihat. Ibn Haitsam, adalah seorang ilmuwan fisika yang paling sadar akan kelemahan indera penglihatan. Beliau menyebutnya ada delapan faktor yang menyebabkan terjadinya kekeliruan dalam pandangan inderawi (mata), yaitu: (1) Kekeliruan karena jarak obyek yang terlalu jauh dari jarak moderat. (2) Kekeliruan karena posisi obyek yang terlalu jauh dari jarak moderat. (3) Kekeliruan karena pencahayaan yang terlalu terang dari pencahayaan moderat. (4) Kekeliruan karena ukuran obyek yang terlalu kecil atau terlalu besar dari ukuran moderat. (5) Kekeliruan karena keburaman yang terlalu pekat. (6) Kekeliruan karena transparansi yang terlalu kuat dari yang moderat. (7) Kekeliruan karena lamanya memandang yang berada di luar batas moderat. (8) Kekeliruan

Ulul Albab, Vol. 10, No. 1, 2009 
karena kondisi mata yang tidak memungkinkan akibat kerusakan yang melampaui batas moderat.

Metode kedua adalah metode logika. Menurut pendukung jalan ini, kepastian dan kebenaran dari sebuah pernyataan (proposisi) filosofis bisa dicapai hanya melalui jalan logis, yakni melalui metode demonstratif. Hal ini bisa dicapai dengan mengikuti secara seksama kaidah-kaidah logika yang baku dan menghindari cara-cara yang keliru atau kurang sempurna sehingga tidak terjerembab pada kekeliruan ketika mengambil kesimpulan (Kartanegara, 2003: 75-83).

Tulisan dalam makalah ini membatasi pada pembicaraan mengenai kebenaran epistemologi yang merupakan kebenaran pengetahuan manusia. Dalam arti apakah dan sejauh manakah pengetahuan itu dapat dikatakan benar? Paham-paham filsafat Barat terbagi menjadi dua kelompok umum, rasionalis dan empiris. Rasionalisme berpendirian, sumber pengetahuan terletak pada akal. Bukan karena rasionalisme mengingkari nilai pengalaman, melainkan pengalaman dipandang sebagai jenis perangsang bagi pikiran. Para penganut rasionalisme yakin bahwa kebenaran dan kesesatan terletak dalam ide kita, dan bukannya dalam diri barang sesuatu. Jika kebenaran mengandung makna mempunyai ide yang sesuai dengan atau menunjuk kepada kenyataan, maka kebenaran hanya dapat ada dalam pikiran kita dan hanya dapat diperoleh dengan akal budi saja (Kattsoff, 1996: 139).

Sedangkan empirisme berkata lain, bahwa jalan untuk memperoleh pengetahuan dengan pengalaman. Yaitu dengan perantara indera, ungkap John Locke, bapak empirisme Britania ini mengatakan, bahwa pada waktu manusia dilahirkan akalnya merupakan sejenis buku catatan yang kosong (tabula rasa), dan di dalam buku catatan itulah dicatat pengalaman inderawi. Menurutnya, seluruh sisa pengetahuan kita peroleh dengan jalan menggunakan serta membandingkan ide-ide yang diperoleh dari penginderaan. la memandang akal sebagai sejenis tempat penampungan, yang secara pasif menerima hasil-hasil penginderaan tersebut. Ini berarti semua pengetahuan kita betapapun rumitnya dapat dilacak kembali sampai kepada pengalaman inderawi yang pertama. Dan sesuatu yang tidak dapat 
dilacak kembali bukanlah pengetahuan, atau setidaknya bukan pengetahuan mengenai hal-hal yang faktual (Kattsoff, 1996: 137).

Contoh nyata dari kelompok pertama (rasionalisme) pada abad ke-19 adalah idealisme Hegel, yang menemukan pengikut di Inggris, dan contoh dari kelompok kedua (empirisme) adalah positivisme yang tetap aktif hingga sekarang. Ludwig Wirtgenstein, Rudolf Carnap, dan Bertrand Russel bisa dihitung sebagai pendukung madzhab ini. Kebanyakan filosof bertuhan adalah rasionalis, dan kebanyakan filosofateis adalah empiris. Contoh ganjit adalah Mc Taggert asal Inggris, yang Hegelian sekaligus ateis.

Idealisme Hegel biarpun punya daya tarik dari sisi sistemnya yang relatif padu, keluasannya, kepastiannya untuk melihat masalah dari beragam perspektif, aliran ini tidak memiliki logika yang kuat dan penalaran yang kukuh. Ada dua macam reaksi sezaman yang berbeda dan kemudian menentangnya, satu dilancarkan Soren Kierkegaard, pendeta Denmark, pendiri eksistensialisme, dan dua dipimpin Karl Marx, Yahudi kelahiran Jerman, pendiri materialisme dialektika.

Pada rasionalisme dan empirisme amat jelas terjadi pertentangan antara akal budi dan pengalaman. Seorang pemikir modern, Immanuel Kant (1724-1804) pada mulanya ia mengikuti rasionalisme, kemudian ia sempat terjagakan oleh Hume (empirisme) dari impiannya, rasionalisme. Tetapi, sebaliknya empirisme tidak diterima begitu saja, karena empirisme membawa keragu-raguan terhadap akal budi. Juga dengan akal budi, ia memiliki batas-batas kemampuan sebagai sumber pengetahuan. Jadi, dalam pandangan Kant, bahwa pengetahuan dapat diperoleh melalui kedua-duanya, yaitu rasionalisme dan empirisme. Sehingga ajarannya disebut rasionalisme kritis (Praja, 1997: 76).

Kecenderungạn yang disokong fenomenologi, Edmund Husserl (1859-1939) ini memunculkan eksistensialisme. Para pemikir, seperti Martin Heidegger dan Karl Jaspers di Jerman, Gabriel Marcel dan Jean Paul Sartre di Prancis menganut filsafat ini dari perspektif yang berbeda, bertuhan dan tidak bertuhan (Yazdi, 2003: 20). Penganut fenomenologi mengatakan 
bahwa sarana untuk memperoleh pengetahuan adalah menggunakan intuisi. Sebagaimana ungkap Husserl, untuk menemukan pemikiran yang benar seseorang harus kembali kepada benda-benda sendiri. Maksudnya, bendabenda diberi kesempatan untuk berbicara tentang hakikatnya sendiri, tidak tergantung kepada orang yang membuat pernyataan. Namun, hakikat benda itu ada dibalik yang kelihatan, bukannya secara langsung memperlihatkan hakikat dirinya. Karena pemikiran pertama tidak membuka tabir yang menutupi hakikat, maka diperlukan pemikiran kedua. Alat yang digunakan pada pemikiran kedua ini adalah intuisi (Praja, 1997: 121).

Pemikir Amerika abad ke-20, William James (1842-1910) dengan pragmatismenya mengatakan, kebenaran adalah makna yang dibangun oleh pikiran untuk memperoleh hasil-hasil praktis yang lebih banyak dan lebih baik. James menyebutnya sebagai empirisme radikal, berbeda dengan empiris lain yang menyangkut bagaimana menentukan wilayah pengalaman. la juga mementingkan kehendak bebas dan peran kreatifnya, yang dari sudut pandang ini ia bermufakat dengan para eksistensialis (Yazdi, 2003: 22). Penganut pragmatisme menaruh perhatian pada praktek. Mereka memandang hidup manusia sebagai suatu perjuangan untuk hidup yang berlangsung terus menerus yang di dalamnya terpenting adalah konsekuensi yang bersifat praktis. Konsekuensi yang bersifat praktis ini erat hubungannya dengan makna dan kebenaran. C. S. Peirce mengatakan, untuk memastikan makna apakah yang dikandung sebuah konsepsi akal maka kita harus memperhatikan konsekuensi praktis yang akan timbul dari kebenaran tersebut (Kattsoff, 1996: 130).

Pandangan lain, positivisme yang diangkat Auguste Comte (17981857), kiranya dapat dinyatakan, bahwa Comte merupakan jembatan antara rasionalisme Descartes di satu pihak, dan empirisme Bacon di lain pihak. la berpendapat, ilmu pengetahuan bisa diperoleh melalui sarana empirik, dengan kata lain anti metafisika. Agar tidak terjadi kesalahpahaman mengenai positivisme, penulis berusaha menjelaskan dengan mengutip pendapat Koento Wibisono sebagai berikut; Pertama, positif diartikan sebagai pensifatan sesuatu yang nyata. Hal ini sesuai dengan ajarannya yang 
menyatakan bahwa filsafat positivisme dalam menyelidiki obyek sasarannya didasarkan pada kemampuan akal. Kedua, positif diartikan sebagai pensifatan sesuatu yang bermanfaat. Hal ini sesuai dengan ajarannya yang menyatakan bahwa dalam filsafat positivisme segala sesuatu harus diarahkan kepada pencapaian kemajuan. Ketiga, positif diartikan sebagai pensifatan sesuatu yang sudah pasti. Hal ini sesuai dengan ajarannya yang menyatakan bahwa filsafat harus sampai pada suatu keseimbangan yang logis yang membawa kebaikan bagi setiap individu dan masyarakat. Keempat, positif diartikan sebagai penafsiran sesuatu yang jelas atau tepat. Hal ini sesuai dengan ajarannya yang menyatakan bahwa dalam pemikiran filsafati kita harus dapat memberikan pengertian yang jelas atau tepat, baik mengenai gejala yang nampak maupun mengenai apa yang sebenarnya kita butuhkan. Kelima, positif dipergunakan untuk menunjukkan sifat-sifat pandangan filsafatnya yang selalu menuju ke arah penataan (Wibisono, 1983: 37).

Juga tidak ketinggalan, dalam mencari kebenaran ilmu pengetahuan muncul teori baru di abad modern ini, yaitu hermeneutik. Sebagai sebuah madzhab pemikiran dan metode filsafat, hermeneutika memang belum berlaku secara universal, tetapi metode ini sangat berguna untuk mendukung pemahaman kita tentang kebenaran dan interpretasi teks secara filosofis, khususnya dalam filsafat ilmu sosial, seni, bahasa, dan sastra (Sumaryono, 1999: 23).

Istilah hermeneutika sebagai ilmu tafsir pertama kali muncul pada sekitar abad ke-17 dengan dua pengertian, yaitu hermeneutika sebagai seperangkat prinsip metodologis penafsiran, dan hermeneutika sebagai penggalian filosofis dari sifat dan kondisi yang tidak bisa dihindarkan dari kegiatan memahami. Carl Braathen merupakan filosof yang mengakomodasi dua pengertian di atas menjadi satu pemahaman. Ia menyatakan, hermeneurika adalah ilmu yang merefleksikan bagaimana satu kata atau peristiwa di masa dan kondisi yang lalu bisa dipahami dan menjadi bermakna secara nyata di masa sekarang, sekaligus mengandung aturan metodologis untuk diaplikasikan dalam penafsiran dan asumsi metodologis dari aktivitas pemahaman (Fakhruddin Faiz, 2002: 10). Mengutip Ekky al Malaky, Paul 
Ricour mengatakan, hermeneutika adalah teori pengoperasian pemahaman dalam hubungannya dengan interpretasi teks. Langkah-langkahnya: (1) pemahaman simbolik (semantik), (2) pemberian makna (reflektif), dan (3) filosofis. (eksistensialis atau ontologis) (al Malaky, 2001: 37).

Untuk obyek-obyek yang bersifat fisik atau inderawi para filosof muslim menggunakan metode observasi. Al Kindi misalnya, dikenal bukan saja sebagai filosof melainkan juga ilmuwan yang menggunakan metode observasi di laboratoriumnya. Mengenai pengetahuan, al Kindi mengelompokkan ke dalam dua jenis, yaitu: (1) Pengetahuan Ilahi, tercantum dalam al Quran yaitu pengetahuan yang diperoleh Nabi dari Tuhan. Dasar pengetahuan ini adalah keyakinan. (2) Pengetahuan manusiawi atau filsafat, dasarnya adalah pemikiran (Nasution, 1973: 12). Kedua pengetahuan ini satu, dengan yang lain tidak bertentangan, hanya dasar argumentasinya berbeda. Dengan perkataan lain, pengetahuan filsafat adalah pengetahuan yang mempergunakan akal, sedangkan pengetahuan Ilahi berasal dari wahyu.

Sebagaimana observasi indera bisa keliru, karena itu dibutuhkan verifikasi terhadap hasil-hasilnya, demikian juga penelitian akal bisa juga keliru, kalau tidak mematuhi aturan-aturan berpikir yang benar, yang kita sebut logika. Logika yang secara formal telah dirumuskan Aristoteles, merupakan metode ilmiah yang menggunakan akal dalam memahami obyekobyek nonfisik. Metode demonstratif (burhani) dipandang sebagai metode yang paling ilmiah, yang diharapkan dapat menangkap realitas obyek-obyek yang ditelitinya dengan tepat, karena telah terhindar dari kekeliruan logis:

Logika merupakan persoalan yang memiliki hubungan erat dengan epistemologi dalam filsafat Ibn Sina. Kedudukan logika dalam filsafat telah lama menjadi sengketa antara kaum Peripatetik yang menganggap logika sebagai alat belaka dalam mencari kebenaran. Sebaliknya, kaum Stoic menganggap logika sebagai bagian dari filsafat. Melihat ini, Ibn Sina berusaha mencari penyelesaiannya dengan memakai analisa jalan tengah.

Jalan yang ditempuhnya beliau menggolongkan filsafat ke dalam bidang pengetahuan. Pengetahuan yang dimaksud adalah mengenai sebab 
(causal). Pengetahuan causal tidak memiliki hubungan dengan logika yang bertitik tolak pada hakikat. Hakikat timbulnya bersama-sama dengan sebab-sebabnya. Kebenaran dapat diperoleh tidak hanya dari unsurnya, tetapi melalui keyakinan yang kuat. Tujuan dari pengetahuan adalah mencari hakikat dan fakta, dan diterima sebagai istilah perantara dalam silogisme. Hasil analisa jalan tengah ini menurut Oemar Amin Hoesin, barang siapa yang memandang filsafat sebagai pelajaran teori dari sudut pandangan seluruhnya, akan menganggap bahwa logika itu menjadi bagian filsafat dan menjadi alat bagiannya. Dari keterangan ini, nampak Ibn Sina lebih cenderung meletakkan logika sebagai alat untuk berfilsafat (Hoesin, 1975: 118).

Juga dengan Ibn Bajjah, beliau menyatakan bahwa untuk memperoleh kebenaran manusia harus melalui kebenaran itu sendiri. Untuk sampai ke tingkat itu alatnya adalah filsafat murni. Dengan filsafat murni itulah manusia dapat membersihkan dirinya dari pengaruh luar. Dan pada gilirannya untuk memperoleh kebenaran manusia meleburkan dirinya dengan akal fa'al (aktif) (Fakhry, 2001: 99).

Meskipun demikian, perlu diingat bahwa akal bukan satu-satunyn alat yang bisa kita gunakan untuk menangkap realitas-realitas nonfisik. Karena selain akal manusia juga dikaruniai Tuhan berupa hati, atau intuisi. Berbeda dengan pendekatan rasional, pendekatan intuitif disebut pendekatan presensial karena obyeknya hadir dalam jiwa seseorang. Sebab itu, modus ilmu seperti itu disebut ilmu huduri (knowledge by presence). Selain obyeknya hadir, obyek tersebut bisa diketahui secara langsung karena tidak ada lagi jurang yang memisahkan kita dengan obyek itu, di sini terjadi kesatuan antara subyek dan obyek, antara yang mengetahui dan yang diketahui. Maka dalam dunia Islam dihiasi dengan karya-karya mistik seperti, fushush althikam dan futuhat al-makkiyah karya Ibn Arabi (w. 1214 M), al-matsnawi al-ma nawi karya al Din Rumi (w. 1273 M), dan seterusnya.

Dapat disimpulkan, bahwa ada tiga cara metode dalam epistemologi Islam untuk menangkap atau mengetahui obyek-obyek ilmu. Pertama, melalui indera yang sangat kompeten untuk mengenal obyek-obyek fisik dengan cara

Ulul Albab, Vol. 10, No. 1, 2009 
mengamatinya. Kedua, melalui akal yang mampu mengenal bukan saja benda inderawi dengan cara mengabstraksi makna universal dari data-data indera, melainkan juga obyek nonfisik dengan cara menyimpulkan dari yang telah diketahui. Ketiga, hati (qalb) yang dapat menangkap obyek-obyek nonfisik atau metafisika melalui kontak langsung dengan obyek-obyeknya yang hadir dalam jiwa seseorang. Dengan demikian, seluruh rangkaian wujud yang menjadi obyek ilmu pengetahuan (yang fisik dan non-fisik) dapat diketahui manusia (Kartanegara, 2002: 66).

Hemat penulis, sesungguhnya semua aliran dalam mencari kebenaran mengenai ilmu pengetahuan sama-sama memiliki kelebihan dan kekurangan. Hal itu sangat tergantung kepada obyek yang menjadi sasaran atau yang. diteliti. Misalnya, aliran rasionalisme, pemakaian logika (rasio) dalam aliran ini dipandang sangat ilmiah karena obyek sasarannya adalah dunia filsafat. Aliran ini digagas oleh Rene Descartes (1595-1650) di mana ia dikenal sebagai pelopor filsafat di abad modern. Empirisme yang dibangun Thomas Hobbes (1588-1679) madzhab ini muncul tidak lepas dari situasi yang melingkarinya. la melukiskan manusia ketika mereka hidup dalam keadaan yang ia namakan state of nature (keadaan alamiah) yang merupakan kondisi manusia sebelum dicetuskan sebuah negara atau masyarakat yang beradab. Karena itu, manusia menginginkan kelangsungan hidup yang penuh perdamaian (Praja, 1997: 71).

- Juga dengan fenomenologi Edmund Husserl yang muncul setelah revolusi Perancis di mana tatanan masyarakat porak poranda, kehilangan nilai-nilai etis dalam kehidupan. Aliran ini muncul sebagai reaksi terhadap positivisme, materialisme, dan scientisme. Begitu pula dengan aliran-aliran lainnya.

Dalam kajian epistemologi selanjutnya, penulis memfokuskan pada madzhab rasionalisme, empirisme, dan fenomenologi. Dengan pertimbangan, bahwa ketiga aliran ini sesuai dengan mekanisme dalam epistemologi Islam. Rasionalisme menekankan kepada akal, dan empirisme mengandalkan indera. Juga dengan fenomenologi, ia memiliki kesamaan dengan metode yang ketiga dalam epistemologi lslam, yaitu hati (qalb), karena keduanya sama-sama menggunakan pendekatan intuitif.

Ulul Albab, Vol. 10, No. 1, 2009 


\section{Rasionalisme; Empirisme dan Fenomenologi}

Dalam agama Islam ada dimensi-dimensi yang menunjuk pada sisi keislaman seseotang. Dimensi tersebut dikenal dengan sebutan trilogi ajaran Islam, yaitu; iman, Islam, dan ihsan. Dimensi di atas berawal dari sebuah Hadis yang diriwayatkan Imam Bukhari dan Muslim yang menceritakan dialog antara Nabi Muhammad saw dengan malaikat Jibril. Hadis tersebur kurang lebih artinya sebagai berikut:

Nabi Muhammad saw keluar dan seseorang datang menghadap beliau dan bertanya: Hai Rasulullah, apakah yang dimaksud dengan iman?, beliau menjawab; iman adalah engkau percaya kepada Allah, malaikatNya, pertemuan denganNya, para utusanNya, dan percaya pada kebangkitan. Laki-laki itu kemudian bertanya lagi, apakah yang dimaksud dengan Islam?, beliau menjawab, Islam adalah engkau menyembah Allah dan tidak syirik kepadaNya, engkau tegakkan shalat wajib, engkau tunaikan zakat wajib, dan engkau berpuasa pada bulan ramadlan. Laki-laki itu kemudian bertanya lagi, apakah yang dimaksud dengan ihsan? Nabi menjawab, ihsan adalah engkau sembah Allah seakan-akan engkau melihatNya, apabila engkau tidak dapat melihatNya maka yakinilah bahwa Allah melihat kamu.

Setiap pemeluk agama Islam mengetahui dengan pasti bahwa Islam tidak absah tanpa iman, dan iman tidak sempurna tanpa ihsan. Sebaliknya, ihsan adalah muśtahil tanpa iman, dan iman juga mustahil tanpa Islam. Ibn Taimiyah menjelaskan bahwa din (agama) itu terdiri dari tiga unsur, yaitu Islam,iman, dan ihsan. Dalam ketiga unsur itu terselip makna kejenjangan (tingkatan): orang mulai dengan Islam, kemudian berkembang ke arah iman, dan memuncak dalam ihsan. Rujukan Ibn Taimiyah ini adalah al Quran surat al Fathir ayat 32:

Kemudian Kitab itu Kami wariskan kepada orang-orang yang Kami pilih di antara hamba-hamba Kami, lalu di antara mereka ada yang menganiaya diri mereka sendiri, dan di antara mereka ada yang pertengahan, dan di antara mereka ada pula yang lebih cepat berbuat kebaikan dengan izin Allah..

Ulul Albab, Vol. 10, No. 1, 2009 
Ibn Taimiyah menjelaskan sebagai berikut: Pertama, orang-orang yang menerima warisan Kitab suci dengan mempercayai dan berpegang teguh pada ajarannya, namun masih melakukan perbuatan dzalim, adalah orang yang baru berIslam, satu tingkat permulaan dalam kebenaran. Kedua, orang yang menerima warisan Kitab suci itu dapat berkembang menjadi seorang mukmin, tingkat menegah, yaitu orang yang telah terbebas dari perbuatan dzalim namun perbuatan kebajikannya sedang-sedang saja. Ketiga, perjalanan mukmin itu berkembang perbuatan kebajikannya sehingga ia menjadi pelomba perbuatan kebajikan, maka ia mencapai derajat ihsan. Orang yang mencapai tingkat ihsan kata Ibn Taimiyah akan masuk surga tanpa mengalami adzab (Madjid, 1994: 465).

Berangkat dari deskripsi di atas dapat ditarik satu pemahaman bahwa ilmu-ilmu yang terkait dengan persoalan keimanan menjadi pembahasan ilmu tauhid (teologi/ilmu tentang keesaan Tuhan), yang terkait dengan keislaman menjadi kajian fiqh (hukum Islam), dan yang terkait dengan ihsan menjadi garapan tasawwuf (mistik). Menengok pendapat al Ghazali disebutkan bahwa, kelompok teolog dalam mencari kebenaran menggunakan metode logika (akal), kelompok tasawwuf menggunakan metode kontemplasi (Othman, 1981: 93), dan kelompok fuqaha' (ahli hukum Islam) menggunakan metode empirik.

Apabila ilmu-ilmu agama Islam secara makro dikelompokkan kepada tiga bidang, yaitu ilmu tauhid (teologi), ilmu figh (hukum Islam), dan ilmu tasawwuf (mistik), maka pertanyaannya, bagaimana nilai-nilai filsafat ilmu (epistemologi) khususnya aliran rasionalisme, empirisme dan fenomenologi bisa terapkan ke dalam ilmu-ilmu agama lslam dalam rangka mencari hakikat kebenaran pengetahuan?

Logika, yang secara formal dirumuskan Aristoteles merupakan metode ilmiah yang menggunakan akal dalam memahami obyek-obyek non-fisik. Meskipun begitu, para filosof mengakui adanya beberapa tingkat atau jenis dari metode logis ini, dilihat dari keakuratannya yaitu metode poetika (syi `r), retorika (khitab), dialektika (jadal), sofistika (mughalith), dan demonstratif (burhani) (Madjid, 1984: 209).

Ulul Albab, Vol. 10, No. 1, 2009 
Metode demonstratif dipandàng sebagai metode paling ilmiah, yang diharapkan dapat menangkap realitas obyek-obyek yang ditelitinya dengan tepat, karena telah terhindar dari kekeliruan logis (logical fallacies). Menurut filosof (teolog) metode demonstratif ini yang mereka gunakan dalam penelitihan ilmiah, meskipun para teolog sering menggunakan metode dialektika. Perbedaan antara keduanya terletak pada premis mereka, premis demonstratif didasarkan pada pengetahuan ilmiah, sementara premis dialektis pada opini (ra'yu). Misalnya, untuk memastikan bahwa yang kekal di dunia ini hanya Allah, mereka berangkat dari premis-premis yang akurat melalui metode deduktif yang dikembangkannya. Dinyatakan bahwa alam ini berubah-ubah (premis mayor), setiap yang berubah-ubah adalah baru (premis minor), maka konklusinya adalah alam itu baru. Dari kesimpulan ini bisa dipastikan bahwa semua yang ada di dunia ini binasa, kecuali yang menciptakan kebinasaan itu sendiri yangekekal, yaitu Allah.

Hasil penelitian rasional para teolog muslim luar biasa besarnya, seperti, al Farq baina al Firaq, karya Abd al Qahir al Baghdadi, Maqalat Islamiyyin, karya Asy`ari, al Fisal fi al Milal wa al Ahwa' wa al Nihal, karya Ibn Hazm, al Milal'wa al-Nihal, karya al-Shahrastani, al Aqaid al Nafasiyyah, karya al Nasafi, al lqtishad fi al I' tiqad, karya al Ghazali, dan lain-lainnya yang kesemuanya membahas tentang tauhid (keesaan Allah) melalui metode yang mereka kembangkan.

Persepsi indera telah cukup memadai untuk menghindari diri dari banyak bahaya yang sangat diperlukan untuk kelangsungan hidup. Perbedaan dalam metode itu terjadi karena perbedaan sifat dasar dari obyeknya. Untuk obyek yang bersifat fisik para pemikir dan ilmuwan muslim pada umumnya menggunakan metode observasi, yaitu pengamatan inderawi terhadap obyek yang ditelitinya. al Kindi misalnya, dikenal bukan saja sebagai filosof, melainkan juga ilmuwan yang menggunakan metode observasi di laboratorium kimia dan fisikanya. Nashir al Din Thusi mengadakan pengamatan astronomi di observatoriumnya yang amat terkenal di Maraghah. Demikian pula Ibn Haitsam dalam eksperimennya di bidang optik mengenai cahaya dan teori penglihatan (Kartanegara, 2002: 62). 
Juga di dunia fiqh, lahirnya empat Imam madzhab, Imam Malik, Imam Hanafi, Imam Hambali, dan Imam Syafi'i dalam memahami hukumhukum yang ada dalam al Quran dan Hadis mereka juga menggunakan pengamatan inderawi. Bagaimana peristiwa-peristiwa faktual yang terjadi di tengah masyarakat untuk memperoleh kepastian hukum, karena tidak semua hukum dijabarkan secara jelas dalam al Quran maupun Hadis. Pada umumnya, mereka melakukan penelitian dengan metode induktif sesuai dengan tempat mereka tinggal. Karena itu, sangat wajar apabila di antara empat Imam madzhab terjadi perbedaan dalam mengambil keputusan hukum. Hal ini disebabkan karena lingkungan, sosial, budaya, geografi, dan keadaan masyarakat yang berbeda-beda. Misalnya Imam Syafi'i, ketika ia berada di Mesir keputusan hukumnya berbeda saat ia menetap di Baghdad, sehingga ada qaul qadim (fatwa dulu) dan qaul jadid (fatwa baru).

Satu contoh kasus, ketika al Quran maupun Hadis tidak memberikan penjelasan tentang umur berapa seorang wanita dikatakan baligh (mukallaf/ dewasa), Imam Syafi'i kemudian melakukan penelitian kepada para wanita di kota Mesir dengan pendekatan induktifnya. Hasil penelitiannya mengatakan, kebanyakan di antara para wanita itu rata-rata dalam usia 9 tahun telah menstruasi. Maka kesimpulan yang didapat adalah seorang wanita dikatakan baligh apabila ia sudah berusia 9 tahun dan sudah menstruasi.

Demikian seringnya penelitian yang dilakukan para ulama di bidang fiqh, termasuk ulama yang hidup di masa sekarang maka karya-karya mereka di bidang ini sungguh beribuan jilid yang terbit. Di Indonesia saja tidak pernah berhenti, seperti Bahsul Masail di kalangana NU, Majlis Tarjih pada kelompok Muhammadiyah, Majlis Hisbi di jama'ah Persis, dan lainnya.

Meskipun demikian, perlu diingat bahwa akal dan indera bukan satu-satunya alat untuk menggapai ilmu pengetahuan, karena selain keduanya manusia dikaruniai Allah berùpa hati, atau intuisi. Ungkap Suhrawardi, pendekatan hati ini disebut dengan dzauq (presensial) karena obyeknya hadir dalam jiwa seseorang, dan karena itu modus ilmu seperti itu disebut ilmu hudluri (knowledge by presence). Selain itu, obyek-obyek itu juga bisa diketahui secara langsung karena tidak ada lagi jarak yang

Ulul Albab, Vol. 10, No. 1, 2009 
memisahkan antara keduanya (Kartanegara, 2002: 62).

Keistimewaan hati sebagai sumber pengetahuan, secara umum kita bisa mengatakan bahwa intuisi mampu memahami banyak hal yang tidak bisa dipahami akal. Ketika akal tidak mampu memahami wilayah kehidupan emosional manusia, hati kemudian dapat memahaminya. Hati juga mampu memahami keunikan-keunikan setiap peristiwa atau kejadian sehari-hari. Dengan dihindarinya kecenderungan generalisasi dan spesialisasi yang bersifat rasional, intuisi mampu melihat dan menghayati setiap peristiwa sebagai peristiwa yang istimewa dan partikular. Hati dapat memahami pengalaman langsung yang kita rasakan dalam apa yang disebut sebagai pengalaman eksistensial, yaitu pengalaman riil manusia yang dirasakan langsung, bukan sebagaimana yang dikonsepsikan akal.

Terakhir, hati juga mempunyai kemampuan untuk mengenal obyeknya secara lebih akrab dan langsung. Pengetahuan intuitif adalah pengetahuan eksperiensial atau pengetahuan yang didasarkan pada pengalaman. Ja mengerti manis, bukan dari kata orang, melainkan dengan mencicipinya. Selain itu, pengetahuan hati juga disebut presensial karena obyeknya dipandang hadir dalam diri atau jiwa seseorang. Dari sinilah kita dapar mengerti mengapa banyak para sufi (ahli tasawwuf) merasa bersatu dengan Kekasihnya, yaitu Tuhan (Harun Nasution:1986;7-91). Karya yang cukup monumental di antaranya; al Futuhat al Makkiyah karya Ibn Arabi, al-Rislah al Qusairiyah, karya al Qusairi, Insan Kamil, karya al Hallaj, dan lainnya, juga seperti karya para orientalis, The Mystics of Islam, karya Nicholson, RA, Mysticism in World Religion, karya Spencer, $\mathrm{S}$.

\section{Simpulan}

Epistemologi merupakan bagian atau obyek garapan filsafat ilmu yang bersangkutan dengan masalah hakikat dan kebenaran pengetahuan, metode untuk memperoleh pengetahuan, dan sistem yang bertujuan untuk memperoleh realitas kebenaran pengetahuan itu sendiri. Dalam epistemologi banyak aliran-aliran yang membicarakan proses pencarian kebenaran ilmu pengetahuan, misalnya, rasionalisme, empirisme, kritisisme, fenomenologi, 
positivisme, pragmatisme, dan lainya. Masing-masing aliran mempunyai beberapa kelebihan dan kekurangan sesuai dengan perbedaan sifat dasar dari objeknya.

Secara makro, ilmu-ilmu agama Islam dapat dikelompokkan kepada tiga bidang: (1) teologi yang banyak menggunakan rasios (2) fiqh yang banyak menggunakan pengamatan indera, dan (3) tasawwuf yang menggunakan pendekatan intuitif. Dalam epistemologi Islam, sumber pengetahuan yang banyak mempergunakan peran akal atau rasio dikenal dengan istilah metode burhani, sedang yang mempergunakan kemampuan inderawi atau kerangka berpikir induktif dan deduktif di kenal dengan sebutan metode bayani, dan yang mempergunakan kekuatan intuitif disebut dengan metode irfani. Ketiga metode ini kalau dilihat dari perspektif epistemologi yang berkembang di dunia Barat, maka cara kerja metode burhani tidak berbeda dengan aliran rasionalisme, dan cara kerja metode bayani sama dengan aliran empirisme, begitu pula dengan metode irfani, cara kerjanya identik dengan aliran fenomenologi. Oleh karena itu, dengan pemaparan ini maka metode untuk memperoleh hakikat kebenaran pengetahuan dalam ilmu-ilmu agama Islam, yaitu teologi, fiqh, dan tasawwuf memiliki titik temu atau perjumpaan metode. Teologi yang menggunakan metode burhani bertemu pada aliran rasionalisme, fiqh yang menggunakan metode bayani berjumpa dengan aliran empirisme, tasawwuf yang menggunakan kekuatan dan kebersihan hati beriring dengan aliran fenomenologi.

Ulul Albab, Vol. 10, No. 1, 2009 


\section{Daftar Pustaka}

Al Quran al Karim. Terjemahan oleh Depag, RI, 2000.

Amien, Miska Muhammad. 1983. Epistemologi Islam. Jakarta: UI Press.

Bakar, Osman. 1997. Hierarki Ilmu: Membangun Rangka Pikir Islamisasi Ilmu. Bandung: Mizan.

D. Runes, Dagobert. 1971. Dictionary of Philosophy. Totowa New Jersey: Adams \& Co.

Faiz, Fakhruddin. 2002. Hermeneutika Qurani: Antara Teks, Konteks, dan Kontekstualisasi. Yogyakarta: Qalam.

Fakhry, Majid. 2001. Sejarah Filsafat Islam: Sebuah Peta Kronologis. Terjemahan oleh Zainul Am. Bandung: Mizan.

Hoesin, Oemar Amin. 1975. Filsafat Islam. Jakarta: Bulan Bintang.

Kartanegara, Mulyadhi. 2002. Menembus batas Waktu: Panorama Filsafat Islam. Bandung: Mizan.

-m. 2003. Menyibak Tirai Kejahilan: Pengantar Epistemologi Islam. Bandung: Mizan.

Kattsoff, Louis O. 1996. Pengantar Filsafat. Terjemahan oleh Soejono Soemargono. Yogyakarta; Tiara Wacana Yogya.

Leaman, Oliver. 2001. Pengantar Filsafat Islam Sebuah Pendekatan Tematis. Terjemahan oleh Musa Kazhim dan Arif Mulyadi. Bandung: Mizan.

Ma`arif, A. Syafi`i. 1993. Peta Bumi Intelektualisme Islam di Indonesia Bandung: Mizan.

al-Malaky, Ekky. 2001. Filsafat Untuk Semua: Pengantar Mudah Menuju Dunia. Jakarta: Lentera.

Madjid, Nurcholis. 1994. Kontekstualisasi Doktrin Islam dalam Sejarah. (Ed.) Budhy Munawwar Rachman. Jakarta: Paramadina.

-m. (Ed). 1984. Khazanah Intelektual Islam. Jakarta: Bulan Bintang.

Muhaimin. 2003. Wacana Pengembangan Pendidikan Islam. Surabaya: Pustaka 
Pelajar.

Muslim. Tt. Shahih al-Muslim. Bandung: Dahlan.

Nasution, Harun. 1973. Filsafat dan Mistisisme dalam Islam. Jakarta: Bulan Bintang.

-m. 1986. Islam Ditinjau dari Berbagai Aspeknya, Jilid II. Jakarta: UI Press.

Othman, Ali Issa. 1981. Manusia Menurut al-Ghazali. Terjemahan oleh Anas Mahyuddin, dkk. Bandung: Pustaka Salaman ITB.

Palmer, Richard E. 1969. Hermeneutics Interpretation Theory in Schleimacher, Dilthey, Heidegger, and Gadamer. Northwestren University Press: Evanston.

Pranarka, A. M. W. 1987. Epistemologi Dasar Suatu Pengantar . Jakarta: Yayasan Proklamasi Centre For Strategic and International Studies (CSIS).

Poedjawijatna, I. R. 1986. Pembimbing ke Arah Alam Filsafat. Jakarta: Bina Askara.

Praja, Juhaya S. 1997. Aliran-Aliran Filsafat dan Etika Suatu Pengantar Bandung: Yayasan Piara.

Rapar, Jan Hendrik. 1996. Pengantar Filsafat. Yogyakarta: Kanisius.

Sumaryono, E. 1999. Hermeneutika: Sebuah Metode Filsafat. Yogyakarta: Kanisius.

Suriasumantri, Jujun S. 1999. Ilmu dalam Perspektif. Jakarta: Yayasan Obor Indonesia.

-1999. Filsafat Ilmu Sebuah Pengantar Populer. Jakarata: Pustaka Sinar Harapan.

Wibisono, Koento. 1983. Arti Perkembangan Menurut Filsafat Positivisme Auguste Comte. Yogyakarta: Gadjah Mada University Press.

Yazdi, Muhammad Taqi Misbah. 2003. Buku Daras Filsafat Islam Terjemahan oleh Musa Kazhim dan Saleh Bagir. Bandung: Mizan. 